\title{
LUPUS DISEASE WITH LUPUS NEPHRITIS - 14 YEARS OF CLINICAL-BIOLOGICAL OBSERVATIONS
}

\author{
Cristina Buhoară ${ }^{1}$, Nicoleta Petre 2 , Mircea Penescu² \\ ${ }^{1}$ Clinical Hospital of Nephrology "Dr. Carol Davila", Bucharest \\ "Carol Davila" University of Medicine and Pharmacy, Bucharest \\ E-mail: cristinabuhoara@yahoo.com
}

\begin{abstract}
We present the case of a female patient diagnosed in 2004 with systemic lupus erythematosus, initially with joint and hematological damage complaint, for which she was treated with Methylprednisolone for 6 months. Subsequently, symptomatology and paraclinical screening raised the suspicion of renal impairment, a pulse therapy with Solumedrol and Cyclophosphamide was initiated, a total of 6 pulses. She is in the database of our Clinic since March 2008, when a renal biopsy was performed, revealing a class IV lupus nephritis, initiating treatment with Mycophenolate mofetil and Prednisone until 2010, when the dose of Prednisone is progressively reduced until cessation at the time of remission. Subsequently she presented two relapse episodes, recovered by pulse therapy with Methylprednisolone and Cyclophosphamide, followed by maintenance therapy with Mycophenolate mofetil and Prednisone with a good clinical evolution. In 2017 the patient has a pregnancy with favorable evolution (under treatment with Azathioprine), presenting normal values of CDNA, C3, C4 during the 9 months, but with a persistent nephrotic-range proteinuria; in these conditions gives birth physiologically at 37 weeks. During 2019 apparent remission is maintained (stationary nitrogen retention, anti-dsDNA antibodies within normal range), but with moderate anaemia and persistent, but diminished proteinuria (being under treatment with reduced dose Prednisolone and Mycophenolate mofetil); along the way proteinuria is accentuated again and it is decided to return to reduced dose Azathioprine treatment, with good clinical evolution.
\end{abstract}

Conclusion. The presented case reinforces the idea of systematic monitoring of patients with SLE and the need for permanent adaptation of treatment especially when there is an increased risk of relapse. Pregnancy, paradoxically well tolerated, increases subsequently the risk of reactivation of lupus nephritis.

Keywords: systemic lupus erythematosus, lupus nephritis, immunosuppression, renal biopsy, pregnancy. 


\section{INTE}

\section{Rezumat}

Prezentăm cazul unei paciente diagnosticată în 2004 cu lupus eritematos sistemic, acuzând inițial afectare articulară şi hematologică, pentru care a fost tratată cu metilprednisolon timp de 6 luni. Ulterior, simptomatologia şi screeningul paraclinic ridicând suspiciunea afectării renale, a fost inițiată pulsterapie cu solumedrol şi ciclofosfamidă, în total 6 pulsuri. Este în evidenţa clinicii noastre din martie 2008, când s-a efectuat puncţie biopsie renală care a evidenţiat nefropatie lupică clasa IV, iniţiindu-se tratament cu micofenolat mofetil şi prednison până în 2010, când se reduce progresiv doza de prednison până la sistare în momentul obținerii remisiunii. Ulterior a prezentat două episoade de recădere ce au fost recuperate prin pulsterapie cu metilprednisolon şi ciclofosfamidă, urmate de tratament de întreţinere cu micofenolat mofetil şi prednison, cu evoluţie clinică bună.

In 2017, pacienta are o sarcină cu evoluţie favorabilă (sub tratament cu azatioprină), prezentând pe parcursul celor 9 luni valori normale ale ADNdc, C3, C4, dar cu proteinurie de rang nefrotic persistentă; în aceste condiţii prezintă naştere fiziologică la 37 de săptămâni. Pe parcursul anului 2019 se menține remisiunea aparentă (retenţie azotată staționară, Ac anti ADNdc în limite normale), dar cu anemie moderată și proteinurie persistentă dar diminuată (fiind sub tratament cu prednisolon doză redusă și micofenolat mofetil); pe parcurs proteinuria se accentuează din nou şi se decide revenirea la azatioprină în doză redusă, cu evoluţie clinică bună.

Concluzie. Situaţia prezentată întăreşte ideea monitorizării sistematice a pacienţilor cu LES şi necesitatea adaptării permanente a tratamentului, mai ales atunci când există risc crescut de recidive. Sarcina, în mod paradoxal bine tolerată, creşte ulterior riscul de reactivare a nefritei lupice.

Cuvinte cheie: lupus eritematos sistemic, nefropatie lupică, imunosupresie, puncţie biopsie renală, sarcină. 


\section{Introduction}

Systemic Lupus Erythematosus (SLE) is a chronic, autoimmune, complex disease that affects multiple organ systems. Understanding the epidemiology, genetic susceptibility and pathophysiological mechanisms has evolved, but it remains a disease with unstable evolution and considerable inter-individual variability. It has an unpredictable prognosis, depending mainly on the severity of the disease activity, the organ damage and the response to treatment. SLE is characterized by the loss of autoimmune tolerance, excessive production of autoantibodies and the development of immune complexes (IC) which precipitate in tissues, causing chronic systemic inflammation and organ lesions ${ }^{(1)}$.

The prevalence of SLE is between 20-150 cases per 100,000 , varies by ethnicity (more common in non-Caucasian persons), by gender (female-to-male ratio 9:1), by age ( $65 \%$ of the patients are aged between 16 $55)^{(2)}$. In addition to endogenous factors (gender, age, hormones), it is also known that certain environmental factors (mental stress, viral infections, smoking, chemical substances, nutrition) influence the course of the disease and can trigger it ${ }^{(3)}$.

Lupus nephritis (LN) occurs in more than $60 \%$ of patients, most commonly in the first 5 years, usually in the first year after the diagnosis of SLE, is one of the most severe organ lesions in $\mathrm{SLE}^{(4)}$.

\section{Case presentation}

We present the case of a female patient, known with SLE with renal, joint and haematological manifestations.

The disease made its onset in March 2004 by painful swelling localized to the proximal interphalangeal joints of the hand and the feet bilaterally, then left knee and right ankle, interpreted in the context of reactive arthritis with genital triggering (inflammatory syndrome, leucorrhea, positive for antiChlamydia IgM antibodies). She followed treatment with Doxycycline and nonsteroidal anti-inflammatory drugs (NSAIDs), interrupting treatment after one month due to esophageal candidiasis.

Subsequently, the patient was hospitalized in a Rheumatology clinic with persistent arthritis of the knees, ankles bilaterally; inflammatory syndrome, leukopenia with lymphopenia, decrease of complement C3, C4, positive anti-dsDNA antibodies (228 $\mathrm{IU} / \mathrm{mL}$ ) were detected by bio-humoral investigations, with the diagnosis of SLE with joint and haematological manifestations. She was administered treatment with NSAIDs and Hydroxychloroquine, discontinued after a few days due to cutaneous allergy. Subsequently, she followed treatment with Methylprednisolone $16 \mathrm{mg} /$ day, discontinued on her own initiative after about 6 months.

During the treatment break, after prolonged exposure to the sun, renal impairment is detected for the first time, manifested by massive edemas in the context of nephrotic syndrome (proteinuria $6 \mathrm{~g} / 24 \mathrm{~h}$ ), hypoproteinemia and hypoalbuminemia. Pulses of Solumedrol $250 \mathrm{mg} \times 3$ days and Cyclophosphamide $1 \mathrm{~g}$, then $600 \mathrm{mg}$, are started, a total of 6 pulses every 6 weeks (last pulse in January 2008); between the pulses followed treatment with Prednisone $1 \mathrm{mg} / \mathrm{kg}$ bw/day. Over time she presented an episode of corticosteroid-induced psychosis, with favorable evolution after reducing the dose of cortisone and antipsychotic therapy.

\section{Symptomatology}

When hospitalized in our clinic, the patient 


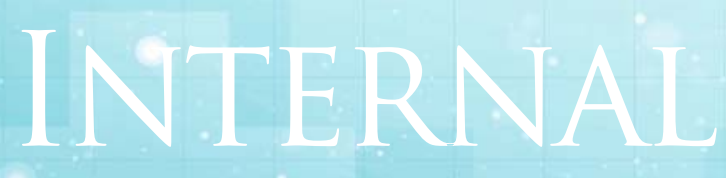

Clinical Cases.

was afebrile, normal weight, slightly pale skin and mucous membranes, without edema, $\mathrm{BP}=105 / 60 \mathrm{mmHg}, \mathrm{HR}=84 \mathrm{bpm}$.

Laboratory evaluation reveals serology suggestive of active SLE: increased titer of anti-dsDNA antibodies, decrease of complement C4, increased ESR, anemia, lymphopenia; low levels of anti-cardiolipin IgG, IgM antibodies. Renal impairment consists of acute nephritic syndrome hematuria with dysmorphic red blood cells, discrete nitrogen retention syndrome associated with nephrotic syndrome: proteinuria $5.18 \mathrm{~g} / \mathrm{g}$ of creatinine, hypoproteinemia.

\section{Diagnosis}

Association of joint, renal (hematuria, proteinuria, increase of serum creatinine), haematological (anemia, lymphopenia, anticardiolipin antibodies) manifestations with a n ti-dsDNA a n tibodies a nd hypocomplementemia support the diagnosis of SLE. The severe SLE activity (SLEDAI 24) and reduced chronic lesions (SDI 0.3) are in accordance with the relatively short time elapsed between the diagnosis and therapeutic intervention.

Lupus nephritis stays active. For determining renal impairment in the context of lupus disease, renal biopsy was performed.

The histopathology examination in optical microscopy reveals diffuse mesangiocapillary proliferation, with accentuation of lobulation in all 10 glomeruli present on the examined fragment. Two glomeruli associated extracapillary cell proliferation. Some capillary loops present thickened walls (Figure 1, 2). The examination in electronic microscopy revealed the presence of amorphousappearing dense subendothelial, mesangial and subepithelial deposits (Figure 3, 4, 5).

The immunofluorescence examination shows 'full house' positivity (IgG, IgA, IgM, Clq, C3, $K, K$ intense granular, coarse positivity in glomerular areas - Figure 6 and 7).

The histopathological diagnosis was according to the ISN/RSPs classification, 2004 of diffuse global proliferative lupus nephritis (class IV G (activity index 14/24 : chronicity index 0/12).

\section{Evolution}

Systemic and renal activity required the continuation of maintenance treatment with Methylprednisolone $16 \mathrm{mg}$ every 2 days and Mycophenolate mofetil 2g/day. Because the anticardiolipin antibody titre was low, the activated thromboplastin time was normal and thromboembolic events were absent, anticoagulant treatment was not considered necessary.

Subsequently, treatment with Mycophenolate mofetil was discontinued and 

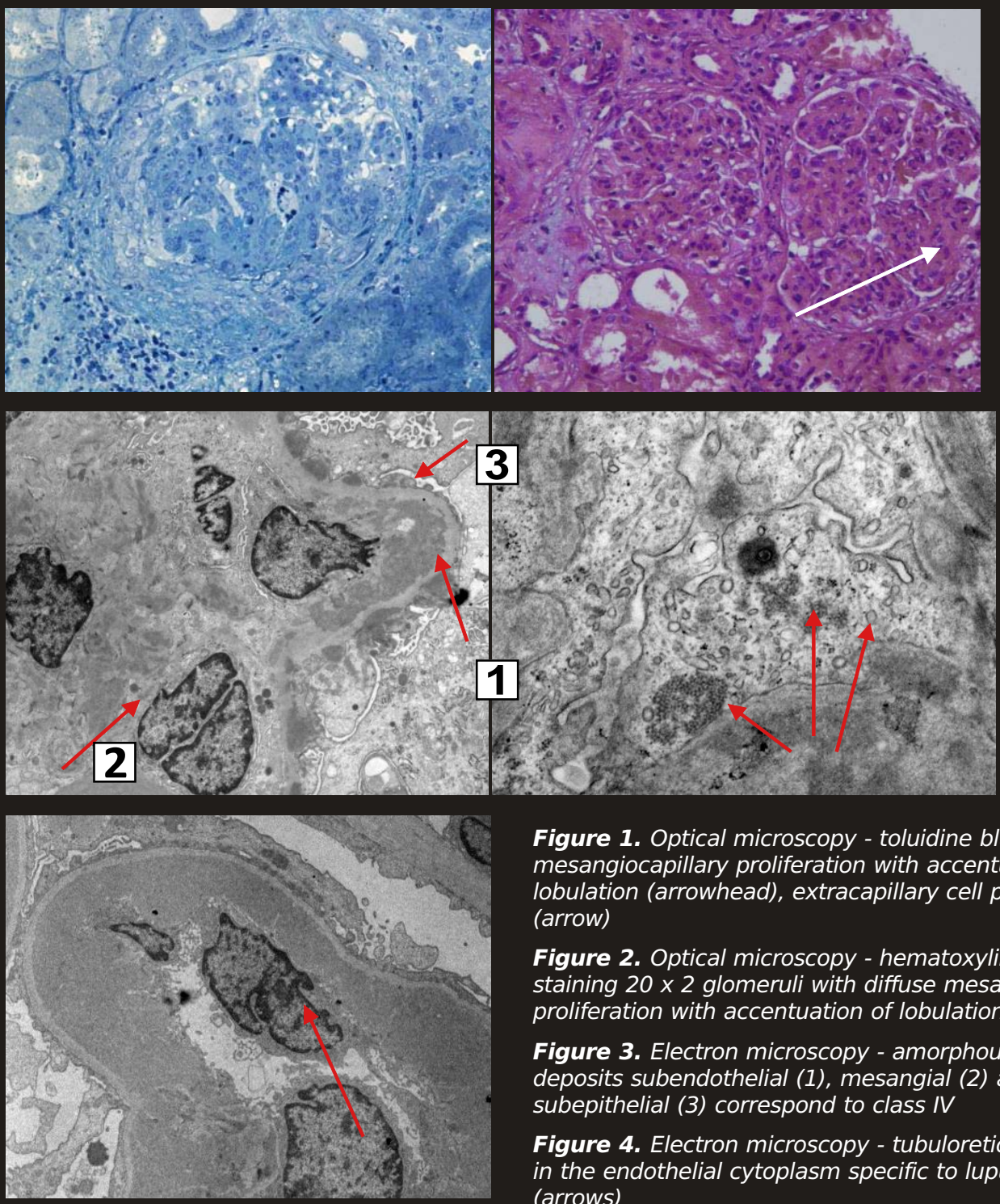

Figure 1. Optical microscopy - toluidine blue, $20 x$ diffuse mesangiocapillary proliferation with accentuation of lobulation (arrowhead), extracapillary cell proliferation (arrow)

Figure 2. Optical microscopy - hematoxylin and eosin staining $20 \times 2$ glomeruli with diffuse mesangiocapillary proliferation with accentuation of lobulation (arrow)

Figure 3. Electron microscopy - amorphous dense deposits subendothelial (1), mesangial (2) and subepithelial (3) correspond to class IV

Figure 4. Electron microscopy - tubuloreticular structure in the endothelial cytoplasm specific to lupus disease (arrows)

Figure 5. Massive, dense subendothelial deposit with wire loop continuous appearance
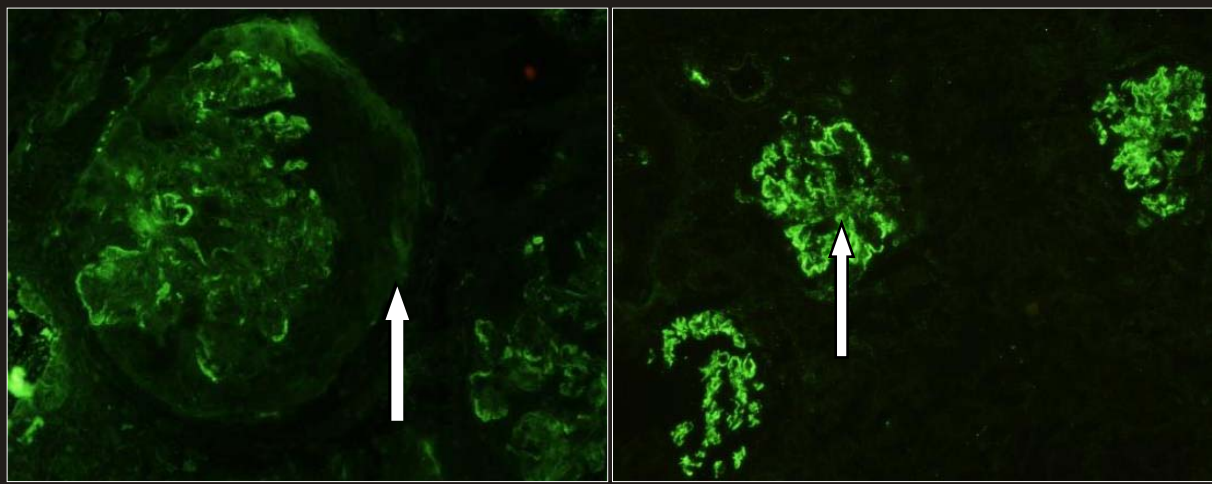

Figure 6. Immunofluorescence: Intensely positive IgG in capillary loops and in mesangium, semilunar extracapillary proliferation

Figure 7. Immunofluorescence C1q intensely positive mesangio - capillary (class IV) The images belong to the collection of "Carol Davila" Clinical Hospital of Nephrology, Bucharest 


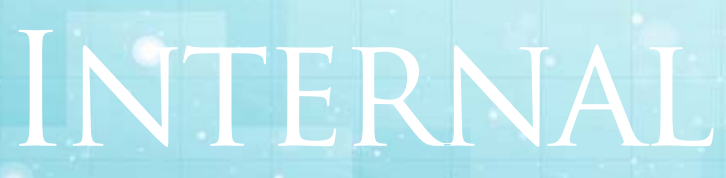

Clinical Cases.

the Prednisone dose was progressively reduced until cessation. Approximately 4 months after treatment cessation, patient presents with the first relapse, by recurrence of initial bilateral proximal interphalangeal and metacarpophalangeal arthralgia, then in the wrists, elbows, shoulders, knees, significant bilateral edema in the legs, sacral and periorbital edema, as well as elevated $\mathrm{BP}$ $(B P=160 \mathrm{mmHg}$ ), headache, anterior epistaxis, all with onset about a month before hospitalization. The biological presentation reveals inflammatory syndrome, severe anaemia $(6.1 \mathrm{~g} / \mathrm{dL})$, leukopenia $\left(2900 / \mathrm{mm}^{3}\right)$ with granulocytopenia $\left(1100 / \mathrm{mm}^{3}\right)$, thrombocytopenia $\left(126,000 / \mathrm{mm}^{3}\right)$, increased nitrogen retention compared to the last clinical evaluation (serum creatinine $=1.67$ $\mathrm{mg} / \mathrm{dL}$, urea $=147 \mathrm{mg} / \mathrm{dL}$, uric acid $=7.4$ $\mathrm{mg} / \mathrm{dL}$ eRFG-MDRD $=41 \mathrm{~mL} / \mathrm{min} / 1.73 \mathrm{~m}^{2}$ ), hypoproteinemia, hyperphosphatemia, proteinuria $3.84 \mathrm{~g} / 24 \mathrm{~h}$, active urinary sediment (leukocytes 240, red blood cells $=130$ ), hypocomplementemia, ANA positive, anti-dsDNA $A b=839 \mathrm{lU} / \mathrm{mL}$, metabolic acidosis. Abdominal ultrasound suggests chronic (cortical echogenicity grade I) and active (edema of pyramids) renal lesions. Treatment with Solumedrol $2.25 \mathrm{~g}$ (3 days) and Cyclophosphamide, a total dose of $9.4 \mathrm{~g}$ was resumed, with a favorable evolution.

Approximately one year after partial remission, the patient presents with the 2 nd episode of relapse (oliguria, hypertension, anemia, anti-dsDNA $A b=605 \mathrm{IU} / \mathrm{mL}$ ), the induction treatment with Methylprednisolone $2 \mathrm{~g}$ and Cyclophosphamide $600 \mathrm{mg}$ that were well tolerated was resumed, followed by maintenance treatment with Prednisone 20 mg/day.

Given the previous total dose of Cyclophosphamide $(10 \mathrm{~g})$, the treatment was continued with Rituximab $500 \mathrm{mg} / \mathrm{m}^{2}$ (500mg in weekly endovenous infusion, 4 endovenous infusions in total) which has been well tolerated and with favorable evolution (greatly improved anaemia without erythropoietin supplement, stationary renal function). She followed maintenance treatment with Mycophenolate mofetil 1g/day and Prednisone $20 \mathrm{mg} /$ day.

After approximately 3 years of immunosuppressive treatment, proteinuria was slightly influenced, which is why it is decided to replace Mycophenolate mofetil with Azathioprine.

Approximately 6 months after partial remission, the patient becomes pregnant, and in the course of biological determinations the following are detected: proteinuria 6.6 $\mathrm{g} / 24 \mathrm{~h}$, moderate anemia, hypoproteinemia with hypoalbuminemia, discrete (stationary) nitrogen retention. Anti-dsDNA Ab, C3, C4 within normal limits. Under these conditions and under Azathioprine treatment, the 


\begin{tabular}{|c|c|c|}
\hline Class & Name & Definition \\
\hline I & $\begin{array}{l}\text { Minimal mesangial lupus } \\
\text { nephritis }\end{array}$ & $\begin{array}{l}\text { Normal glomeruli by OM, but immune deposits are present } \\
\text { by IF, EM or both }\end{array}$ \\
\hline II & $\begin{array}{l}\text { Mesangial proliferative lupus } \\
\text { nephritis }\end{array}$ & $\begin{array}{l}\text { Purely mesangial hypercellularity of any range or } \\
\text { mesangial matrix expansion (OM) with mesangial immune } \\
\text { deposits (IF) A few isolated immune deposits in } \\
\text { subendothelial or subepithelial deposits visible by IF or EM } \\
\text { are possible, but not by OM }\end{array}$ \\
\hline III & $\begin{array}{l}\text { Focal proliferative lupus } \\
\text { nephritis } \\
\text { Class III (A) } \\
\text { Class III (A/C) } \\
\text { Class III (C) }\end{array}$ & $\begin{array}{l}\text { Active or inactive focal lesions, segmental, and/or global, } \\
\text { endocapillary and/or extracapillary glomerulonephritis, } \\
\text { involving }<50 \% \text { of all glomeruli, characteristically having } \\
\text { focally arranged subendothelial immune deposits, with or } \\
\text { without mesangial involvement. } \\
\text { Focal proliferative lupus nephritis: active lesions } \\
\text { Focal proliferative and sclerosing lupus nephritis: Active } \\
\text { and chronic lesions } \\
\text { Focal sclerosing lupus nephritis: Chronic inactive lesions } \\
\text { with scarred glomerulus }\end{array}$ \\
\hline IV & Diffuse lupus nephritis & $\begin{array}{l}\text { Active or inactive diffuse lesions, segmental, and/or } \\
\text { global, endocapillary and/or extracapillary } \\
\text { glomerulonephritis, involving < } 50 \% \text { of all glomeruli, } \\
\text { characteristically arranged diffusely subendothelial } \\
\text { immune deposits, with or without mesangial involvement. } \\
\text { This class is divided into diffuse segmental proliferative } \\
\text { forms (IV-S), in which }>50 \% \text { of affected glomeruli have } \\
\text { segmental lesions and diffuse global proliferative forms } \\
\text { (IV-G), in which }>50 \% \text { of affected glomerules have global } \\
\text { lesions. Segmental lesion affects less than half of the } \\
\text { capillary bundle. This class includes diffuse 'wire loop' } \\
\text { deposits, involving less or none proliferative lesions. } \\
\text { Diffuse segmental proliferative lupus nephritis: active } \\
\text { lesions }\end{array}$ \\
\hline
\end{tabular}


Clinical Cases.

\begin{tabular}{|c|c|c|}
\hline & $\begin{array}{l}\text { Class IV-S (A) } \\
\text { Class IV-G (A) } \\
\text { Class IV-S (A/C) } \\
\text { Class IV-G (A/C) } \\
\text { Class IV-S (C) } \\
\text { Class IV-G (C) }\end{array}$ & $\begin{array}{l}\text { Segmental proliferative and sclerosing lupus nephritis: } \\
\text { active and chronic lesions } \\
\text { Global proliferative and sclerosing lupus nephritis: active } \\
\text { and chronic lesions } \\
\text { Segmental sclerosing lupus nephritis: chronic lesions } \\
\text { Global sclerosing lupus nephritis: chronic lesions }\end{array}$ \\
\hline $\mathbf{V}$ & Membranous lupus nephritis & $\begin{array}{l}\text { Segmental or global subepithelial immune deposits or } \\
\text { morphologic } \\
\text { sequelae of these deposits visible by OM and IF or EM, } \\
\text { with or without mesangial involvement. It may occur in } \\
\text { overlap with Class III or IV, when both need to be } \\
\text { diagnosed. } \\
\text { Evolves to glomerulosclerosis }\end{array}$ \\
\hline VI & $\begin{array}{l}\text { Advanced sclerosis lupus } \\
\text { nephritis }\end{array}$ & $\begin{array}{l}=90 \% \text { globally sclerosed glomeruli without residual } \\
\text { activity }\end{array}$ \\
\hline
\end{tabular}

Table 1. Histological classification of lupus nephritis of the International Society of Nephrology and Renal Pathology Society (ISN/RPS)(Weening JJ et al, 2004)(5)

OM - optical microscopy; EM - electron microscopy; IF - immunofluorescence 
evolution of pregnancy was still favorable and the patient gave birth at 37 weeks.

Subsequent evolution is characterized by moderate, discretely macrocytic anemia, stationary nitrogen retention and anti-dsDNA Ab within normal limits. However under Prednisolone $10 \mathrm{mg}$ and Mycophenolate mofetil treatment proteinuria is accentuated in time and it is decided to return to reduced dose Azathioprine treatment, with good clinical evolution.

\section{Conclusions}

Proper use of immunosuppressive therapy has allowed improvement of the prognosis of lupus nephritis $(70-75 \%$ of the adequately treated patients respond to treatment) ${ }^{(10)}$. In this case the outcome of LN was favorable, several factors being responsible: firstly, although at the time of the discovery of renal involvement, renal biopsy was not practiced, the initial treatment was intense (Solumedrol and Cyclophosphamide, a total of 6 pulses every 6 weeks), while the studies showed that an important prognostic factor is the response to the attack treatment; secondly, although the lesions found at renal biopsy were proliferative - usually associated with a more severe prognosis, the clinical-biological evolution was favorable; thirdly, the patient's adherence to both the initial treatment and therapeutic regimens with mycophenolate mofetil and then Azathioprine, respectively the treatment followed in the 2 episodes of relapse, contributed to the favourable prognosis.
The particularity of the case consists in the favorable evolution both during pregnancy (known and attributed to the endocrinological context specific to pregnancy with hypersecretion of corticosteroids) and natural birth and favorable postpartum evolution attesting the possibility of procreation under normal circumstances in a patient with properly treated lupus nephritis.

The timing of procreation is essential because the risk of miscarriage is high in women with SLE and increases in those with active disease (over $50 \%$ versus $13 \%$ ), so pregnancy should be planned after remission $^{(6)}$.

\section{References}

1. Lisnevskaia L, Murphy G, Isenberg DA. Systemic lupus erythematosus. Lancet. 2014;384:1878-1888. doi:10.1016/S0140-6736(14)60128-8 (PubMed)

2. Tsokos GC. Systemic lupus erythematosus. N Engl J Med (2011) 365: 2110-2121; Lisnevskaia L, Murphy G, Isenberg $D:$ Systemic lupus erythematosus. Lancet (2014) 384: 1878-1888; Borchers AT, Leibushor $N$, Naguwa SM, Cheema GS, Shoenfeld Y, Gershwin ME. Lupus nephritis: a critical review. Autoimmun Rev (2012) 12: 174-194.

3. Moulton VR. Sex hormones in acquired immunity and autoimmune disease. Front Immunol. 2018;9:2279. doi:10.3389/fimmu.2018.02279 (PubMed)

4. Chambers SA, Allen E, Rahman A, Isenberg $D$. Damage and mortality in a group of British patients with systemic lupus erythematosus followed up for over 10 years. Rheumatology. 2009;48:673-675. (PubMed)

5. Chambers SA, Rahman A, Isenberg DA: Treatment adherence and clinical outcome in systemic lupus Erythematosus. Rheumatology (2007) 46:895-898.

6. Kidney Disease: Improving Global Outcomes (KDIGO) CKD Work Group. KDIGO 2012 Clinical Practice Guideline for the Evaluation and Management of Chronic Kidney Disease. Kidney int, (2013) Suppl 3:1-150. 